\title{
Zoonoses and their traces in ancient genomes - a possible indicator for ancient life-style changes?
}

\author{
Dawid Leciej \\ Department of Pediatric Gastroenterology and Metabolic \\ Diseases, Poznan University of Medical Sciences, Poland \\ (iD) https://orcid.org/0000-0002-8893-6940 \\ Corresponding author: 84658@student.ump.edu.pl

\section{Karl-Heinz Herzig} \\ Department of Pediatric Gastroenterology and \\ Metabolic Diseases, Poznań University of Medical \\ Sciences, Poland; University of Oulu, Research Unit \\ of Biomedicine, Medical Research Center, Faculty of \\ Medicine, Oulu University Hospital, Oulu, Finland \\ (iD) https://orcid.org/0000-0003-4460-2604

\section{Olaf Thalmann} \\ Department of Pediatric Gastroenterology and Metabolic \\ Diseases, Poznan University of Medical Sciences, Poland \\ (iD) https://orcid.org/0000-0003-1700-0130
}

DOI: https://doi.org/10.20883/medical.e467

Keywords: zoonoses, paleoepidemiology, paleogenomics, paleoepigenomics, neolithic, ancient DNA

Published: 2020-09-30

How to cite: Leciej D, Herzig K-H, Thalmann O. Zoonoses and their traces in ancient genomes - a possible indicator for ancient life-style changes?. JMS [Internet]. 2020 Sep 30;89(3):e467. doi:10.20883/medical.e467

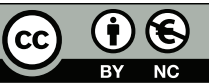

(c) 2020 by the author(s). This is an open access article distributed under the terms and conditions of the Creative Commons Attribution (CC BY-NC) licencse. Published by Poznan University of Medical Sciences

\begin{abstract}
Humans are constantly exposed to health risks inherent to the environment in which they live, thereby including non-human fauna. Zoonoses are infectious diseases caused by agents such as bacteria, parasites, or viruses being transmitted to humans from wild animals and livestock. The close proximity of animals and humans facilitate the spread of zoonoses, so it is intriguing to hypothesize that populations accustomed to different lifestyles will also vary in the prevalence of zoonotic agents. The Neolithic era in human history is characterised by a dramatic transition in lifestyle, from hunting and gathering to farming. Thus, with the changes in the reservoir of animal species humans were exposed to zoonotic agents potentially penetrating human populations. Due to the rapid development of sequencing technologies and methodology in ancient DNA research, it is now possible to generate complete genomes of ancient specimens and pinpoint those genomic regions or epigenetic signatures that might be influenced by past zoonotic transmissions. Unravelling such traces, particularly on a population-scale, will help to overcome the lack of generalisation that hampered previous research focusing exclusively on the model fossils in human evolution, and facilitate a better understanding of the aetiology of diseases, including those caused by zoonotic agents.
\end{abstract}

Humans are constantly exposed to health risks inherent to their environment or facilitated by direct interactions with members of our species or other organisms. Zoonoses are infectious diseases that pose a severe risk to health and while being manifested in human populations, they have their origin in non-human fauna
[1]. Bacteria, parasites, viruses or other agents are transmitted to humans from wild animals and livestock, thereby causing serious illnesses like Ebola and SARS [2, 3]. Zoonoses are tightly linked to human-animal interactions and contemporary exposure can directly be assessed via stool or blood screens, and whenever a genetic marker 


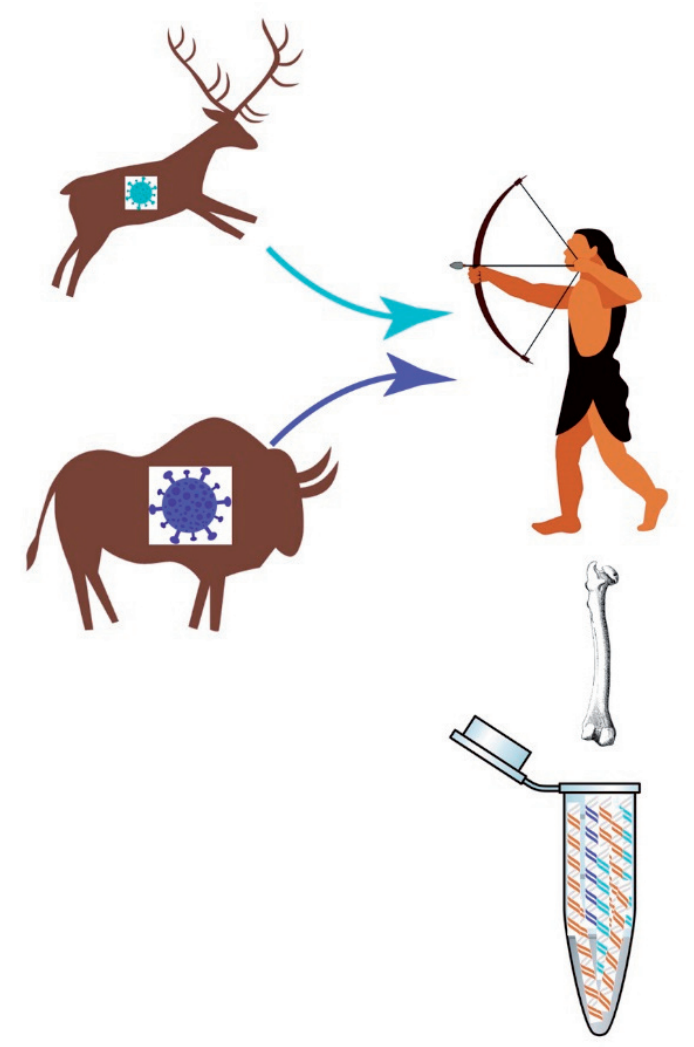

Neolithic Hunter-Gatherers

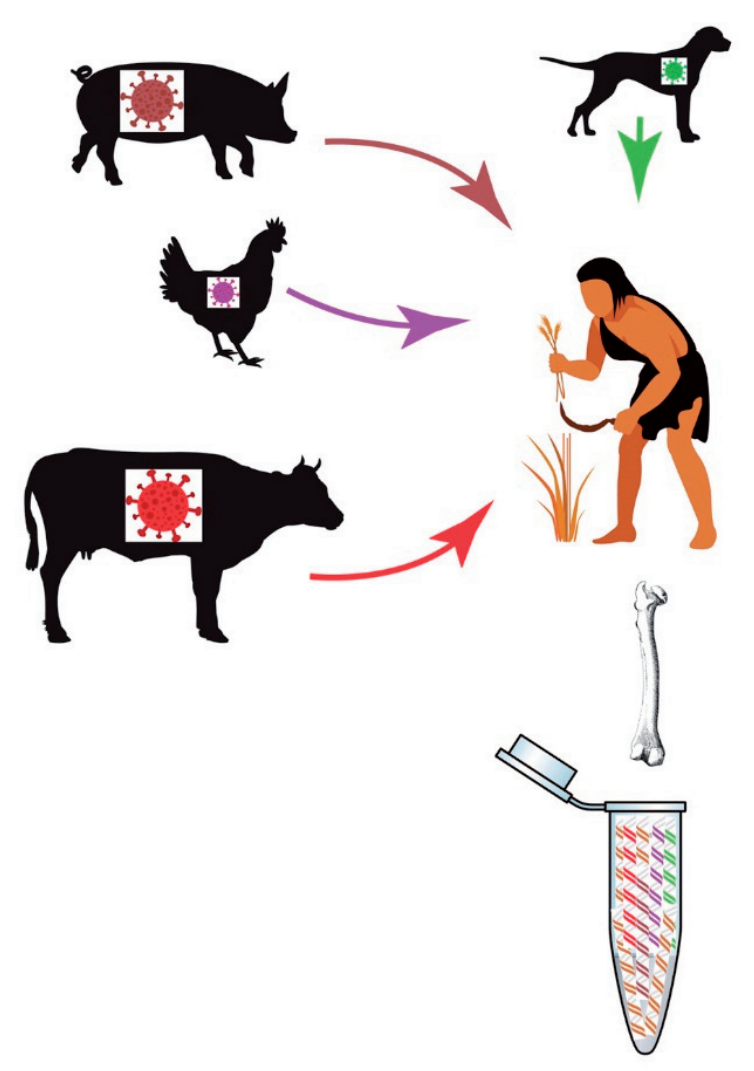

Neolithic Farmers

Figure 1. Graphical depiction of the hypothesis of population differences in zoonoses exposure and detection in Neolithic humans

of the agent becomes available, it can be traced through space and time. A classical example is the emergence and trajectory of various Ebola outbreaks [4], however, while Ebola is most likely associated with recent exposure to the virus, other zoonotic agents entered human populations a long time ago.

It is now intriguing to speculate that various human lifestyles or the transition between them might have facilitated the emergence of zoonoses. One such crucial periods in human history was the Neolithic, in which the shift from huntinggathering to farming occurred. During this era, the agricultural revolution sustainably altered our diet and how communities were organised, thereby allowing cultures to thrive. Most importantly, humans started to interact with animals that ultimately became our domesticates (5). Archaeological evidence and simulation data support the idea of increased zoonotic prevalence due to lifestyle transitions $[6,7]$, however, to explicitly test this hypothesis and evaluate the zoonotic burden of our Neolithic ancestors, we must exploit their respective ancient genomes. First attempts to detect disease agents in ancient genomes have provided encouraging results, suggesting an onset of tuberculosis and plaque as early as 5000 years ago or identifying the trajectory of HBV transmission and its origin 100,000 years ago $[8,9]$. We believe that incorporating populationwide genomic data generated from actual Neolithic human samples would greatly expand current knowledge with respect to zoonoses, possibly providing new evidence regarding the health implications of the Neolithic Revolution. Herein, we discuss the prospects of novel Paleogenomic and Paleoepigenomic approaches in light of the evolution of zoonoses [10].

One major hurdle that needs to be addressed relates to the characteristics of ancient DNA, namely its fragmentation, various damage patterns and low endogenous DNA content [11]. Recent developments in sequencing technologies [12] have enabled us to not only account for these patterns but also to make use of them. It has long been accepted that ancient DNA extracts are 
a mixture of endogenous DNA, environmental, microbiological and modern contaminants [13]. Generating billions of DNA snippets facilitates the investigation of the origin of literally every single DNA fragment obtained from an ancient sample. The prospects are unlimited, and the recent drop in per-base sequencing costs render the 1,000 $\$$ genome rather science than fiction. The length of the molecules sequenced from ancient materials can be indicative of the age of the specimen with shorter fragments representing older material [14], which further helps to differentiate endogenous from contaminant DNA. A comparison of these fragments with genetic databases allows a taxonomic classification of those not mapping to the respective reference genome (i.e. the human genome). Intriguingly, this approach might readily uncover disease agents the specimen was exposed to in the past $[15,16]$. However, the quality of the genome is further determined by its coverage, a measure of how often a single nucleotide has been sequenced from a sample. This is crucial, as the higher the coverage in a particular genomic region, the better the chances of identifying rare variants, including those with health relevance (e.g. encoding viral/pathogen interacting proteins [17]). Despite a qualitative difference in the genes affected by such variances, we would further predict a difference in frequencies observed in populations differentially exposed to zoonotic agents. Alternatively, by screening the endogenous genome, we could detect genetic material potentially incorporated from actual zoonotic agents. Parasites infecting livestock and wild animals can act as media species for horizontal gene transfer [18-20], an often underappreciated but widespread phenomenon [20]. If so, we can hypothesise that two populations accustomed to different diets and ways in which they interact with animals will differ in terms of parasitic infections and horizontally transferred DNA fragments. The methodical approach has been established on modern genomes [18] and its application for ancient DNA should pose no major obstacles. Despite the merits of investigating endogenous DNA, assessing the metagenomic composition of, for instance, dental plaque will further help to not only highlight dietary components but also to evaluate the oral fauna, thereby assess host-pathogen interactions and provide a direct health indicator from the past [21].
A highly covered, high-quality ancient genome is the basis of Paleoepigenomic analyses [12, 22]. It has been suggested that populations with low genetic variation might exhibit higher epigenetic variation leading to the hypothesis that epigenetic mechanisms might act as a fast compensatory mechanism for the adaptation to novel environments [23, 24]. If these patterns are now translated into the Neolithic, it is tempting to speculate that changes in the methylation landscape, the only means to detect epigenetic changes in the past [12], and in particular, those affecting immunological responses might have been triggered by a decreased vicinity and a prolonged exposure to livestock in novel farming communities. Prior to the emergence of next-generation sequencing technologies [25], we simply lacked the means to address Paleoepigenomics questions, but highquality ancient genomes have now produced intriguing results alluding to epigenetic changes in our archaic human ancestors. Gokhman and colleagues provided a first ancient methylation map [22] and were able to identify thousands of differentially methylated sites in the genomes of Denisovan, Neanderthals and modern humans, and by using these maps they proposed a detailed morphological profile of Denisovans [26].

As these studies solely focused on the charismatic models in human evolution, they can merely present an individual assessment, thereby lack generalisation. Consequently, the investigation of population-wide patterns of genomic variation prevalent in the past will help to circumvent such singularity and address patterns of broader relevance for the emergence and prevalence of zoonotic agents during the lifestyle transition in the Neolithic. Such elaborate investigations will not only elevate ancient DNA research to a next level but also allow the evaluation of the effects of lifestyle changes in the past on the aetiology of modern diseases, and our knowledge of the variety and severity of zoonotic agents.

\section{Acknowledgements}

Conflict of interest statement

The authors declare no conflict of interest.

\section{Author contribution}

All authors have discussed the ideas and contributed to the manuscript. 


\section{Funding sources}

Olaf Thalmann received financial support from the Narodowe Centrum Nauki, Poland (2017/26/E/ NZ5/00851).

\section{References}

1. Chomel B. Zoonoses. In: Encyclopedia of Microbiology. Elsevier Inc.; 2009:820-90. https://doi. org/10.1016/B978-012373944-5.00213-3

2. Marí Saéz $A$, Weiss $S$, Nowak $K$, Lapeyre $V$, Zimmermann F, Düx A, Kühl HS, Kaba M, Regnaut $S$, Merkel K, Sachse A, Thiesen U, Villányi L, Boesch C, Dabrowski PW, Radonić A, Nitsche A, Leendertz SAJ, Petterson S, Becker S, Krähling V, Couacy Hymann E, Akoua Koffi C, Weber N, Schaade L, Fahr J, Borchert M, Gogarten JF, Calvignac Spencer S, Leendertz FH. Investigating the zoonotic origin of the West African Ebola epidemic. EMBO Molecular Medicine. 2014 Dec 30;7(1):17-23. https://doi.org/10.15252/ emmm.201404792

3. Field HE. Bats and Emerging Zoonoses: Henipaviruses and SARS. Zoonoses and Public Health. 2009 Aug;56(6-7):278-284. https://doi.org/10.1111/j.18632378.2008.01218.x

4. Walsh PD, Biek R, Real LA. Wave-Like Spread of Ebola Zaire. Harvey P. PLoS Biology. 2005 Oct 25;3(11):e371. https://doi.org/10.1371/journal.pbio.0030371

5. Larson G, Burger J. A population genetics view of animal domestication. Trends in Genetics. 2013 Apr;29(4):197-205. https://doi.org/10.1016/j. tig.2013.01.003

6. Latham K. Human Health and the Neolithic Revolution: An Overview of Impacts of the Agricultural Transition on Oral Health, Epidemiology, and the Human Body. Nebraska Anthropologist. 2013;:187.

7. Fournié G, Pfeiffer DU, Bendrey R. Early animal farming and zoonotic disease dynamics: modelling brucellosis transmission in Neolithic goat populations. Royal Society Open Science. 2017 Feb;4(2):160943. https://doi.org/10.1098/rsos.160943

8. Spyrou MA, Bos KI, Herbig A, Krause J. Ancient pathogen genomics as an emerging tool for infectious disease research. Nature Reviews Genetics. 2019 Apr 5;20(6):323-340. https://doi.org/10.1038/s41576019-0119-1

9. Kahila Bar-Gal G, Kim MJ, Klein A, Shin DH, Oh CS, Kim JW, Kim T, Kim SB, Grant PR, Pappo O, Spigelman $M$, Shouval D. Tracing hepatitis $B$ virus to the 16th century in a Korean mummy. Hepatology. 2012 Oct 14;56(5):1671-1680. https://doi.org/10.1002/ hep. 25852

10. Günther T, Valdiosera C, Malmström H, Ureña I, Rodriguez-Varela $R$, Sverrisdóttir Óo, Daskalaki EA, Skoglund $\mathrm{P}$, Naidoo T, Svensson EM, Bermúdez de Castro JM, Carbonell E, Dunn M, Storå J, Iriarte E, Arsuaga JL, Carretero J, Götherström A, Jakobsson M. Ancient genomes link early farmers from Atapuerca in Spain to modern-day Basques. Proceedings of the National Academy of Sciences. 2015 Sep 8;112(38):11917-11922. https://doi.org/10.1073/ pnas. 1509851112
11. Cooper A. Ancient DNA: Do It Right or Not at All. Science. 2000 Aug 18;289(5482):1139b-1139. https:// doi.org/10.1126/science.289.5482.1139b

12. Orlando L, Gilbert MTP, Willerslev E. Reconstructing ancient genomes and epigenomes. Nature Reviews Genetics. 2015 Jun 9;16(7):395-408. https://doi. org/10.1038/nrg3935

13. Llamas B, Valverde G, Fehren-Schmitz L, Weyrich LS, Cooper A, Haak W. From the field to the laboratory: Controlling DNA contamination in human ancient DNA research in the high-throughput sequencing era. STAR: Science \& Technology of Archaeological Research. 2016 Nov 30;3(1):1-14. https://doi.org/10.1 080/20548923.2016.1258824

14. Sawyer S, Krause J, Guschanski K, Savolainen V, Pääbo S. Temporal Patterns of Nucleotide Misincorporations and DNA Fragmentation in Ancient DNA. Lalueza-Fox C. PLoS ONE. 2012 Mar 30;7(3):e34131. https://doi.org/10.1371/journal.pone.0034131

15. Keller M, Spyrou MA, Scheib CL, Neumann GU, Kröpelin A, Haas-Gebhard B, Päffgen B, Haberstroh J, Ribera i Lacomba A, Raynaud C, Cessford C, Durand R, Stadler P, Nägele K, Bates JS, Trautmann B, Inskip SA, Peters J, Robb JE, Kivisild T, Castex D, McCormick M, Bos $\mathrm{KI}$, Harbeck M, Herbig A, Krause J. Ancient Yersinia pestis genomes from across Western Europe reveal early diversification during the First Pandemic (541-750). Proceedings of the National Academy of Sciences. 2019 Jun 4;116(25):12363-12372. https:// doi.org/10.1073/pnas.1820447116

16. Zink AR, Molnár E, Motamedi N, Pálfy G, Marcsik A, Nerlich AG. Molecular history of tuberculosis from ancient mummies and skeletons. International Journal of Osteoarchaeology. 2007;17(4):380-391. https:// doi.org/10.1002/oa.909

17. Enard D, Petrov DA. Evidence that RNA Viruses Drove Adaptive Introgression between Neanderthals and Modern Humans. Cell. 2018 Oct;175(2):360-371.e13. https://doi.org/10.1016/j.cell.2018.08.034

18. Syvanen M. Cross-species gene transfer; implications for a new theory of evolution. Journal of Theoretical Biology. 1985 Jan;112(2):333-343. https://doi. org/10.1016/s0022-5193(85)80291-5

19. Jain R, Rivera MC, Lake JA. Horizontal gene transfer among genomes: The complexity hypothesis. Proceedings of the National Academy of Sciences. 1999 Mar 30;96(7):3801-3806. https://doi.org/10.1073/ pnas.96.7.3801

20. Crisp A, Boschetti C, Perry M, Tunnacliffe A, Micklem $\mathrm{G}$. Expression of multiple horizontally acquired genes is a hallmark of both vertebrate and invertebrate genomes. Genome Biology. 2015 Mar 13;16(1). https://doi.org/10.1186/s13059-015-0607-3

21. Weyrich LS, Duchene S, Soubrier J, Arriola L, Llamas B, Breen J, Morris AG, Alt KW, Caramelli D, Dresely $V$, Farrell M, Farrer AG, Francken M, Gully N, Haak W, Hardy K, Harvati K, Held P, Holmes EC, Kaidonis J, Lalueza-Fox C, de la Rasilla M, Rosas A, Semal P, Soltysiak A, Townsend G, Usai D, Wahl J, Huson DH, Dobney K, Cooper A. Neanderthal behaviour, diet, and disease inferred from ancient DNA in dental calculus. 
Nature. 2017 Mar 8;544(7650):357-361. https://doi. org/10.1038/nature21674

22. Gokhman D, Lavi E, Prufer K, Fraga MF, Riancho JA, Kelso J, Paabo S, Meshorer E, Carmel L. Reconstructing the DNA Methylation Maps of the Neandertal and the Denisovan. Science. 2014 Apr 17;344(6183):523527. https://doi.org/10.1126/science.1250368

23. Smith TA, Martin MD, Nguyen M, Mendelson TC. Epigenetic divergence as a potential first step in darter speciation. Molecular Ecology. 2016 Mar 14;25(8):18831894. https://doi.org/10.1111/mec.13561

24. Chown SL, Hodgins KA, Griffin PC, Oakeshott JG, Byrne M, Hoffmann AA. Biological invasions, climate change and genomics. Evolutionary Applications. 2014 Dec 9;8(1):23-46. https://doi.org/10.1111/ eva.12234

25. Margulies $M$, Egholm M, Altman WE, Attiya S, Bader JS, Bemben LA, Berka J, Braverman MS, Chen Y,
Chen Z, Dewell SB, Du L, Fierro JM, Gomes XV, Godwin $\mathrm{BC}$, He W, Helgesen S, Ho CH, Irzyk GP, Jando SC, Alenquer MLI, Jarvie TP, Jirage KB, Kim J, Knight JR, Lanza JR, Leamon JH, Lefkowitz SM, Lei M, Li J, Lohman KL, Lu H, Makhijani VB, McDade KE, McKenna MP, Myers EW, Nickerson E, Nobile JR, Plant R, Puc BP, Ronan MT, Roth GT, Sarkis GJ, Simons JF, Simpson JW, Srinivasan M, Tartaro KR, Tomasz A, Vogt KA, Volkmer GA, Wang SH, Wang Y, Weiner MP, Yu P, Begley RF, Rothberg JM. Genome sequencing in microfabricated high-density picolitre reactors. Nature. 2005 Jul 31;437(7057):376-380. https://doi. org/10.1038/nature03959

26. Gokhman D, Mishol N, de Manuel M, de Juan D, Shuqrun J, Meshorer E, Marques-Bonet T, Rak Y, Carmel L. Reconstructing Denisovan Anatomy Using DNA Methylation Maps. Cell. 2019 Sep;179(1):180-192.e10. https://doi.org/10.1016/j.cell.2019.08.035 